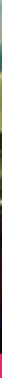

\title{
Forest
}

\section{Making dry forests work for the poor in Africa - building on success}

\section{Lessons learned}

Eradicating poverty is arguably the greatest global challenge facing the world today and is a necessary precondition for sustainable development. To reach the poverty-reduction goals, bold action is required. In this Livelihood Brief we highlight some success stories, showing how sustainable management of forest resources has led to positive livelihood impacts. Four main lessons can be learned from these.

- Forest products can enhance peoples' livelihoods, but creating value requires changing the form or location of the products or the timing of their delivery to markets.

- Entrepreneurship is important. The people who succeeded had the confidence to seize the initiative when opportunities arose.

- Organisation matters; where people can organise themselves they benefit from opportunities to exchange information, learn from each other's experiences, share resources, and undertake joint activities. They have more voice.

- External assistance can make a difference, by helping people improve the quality of their products, gain access to technology and markets, or overcome other barriers to entry.

\section{Liquid gold - building livelihoods and the Zambian economy}

"It is the second honey flow" said Pious Makeche as he scooped comb honey from the bucket in front of the buyer's scales, "and it is pure, liquid gold that will buy my son a bicycle to go to school." The second honey flow occurs between March and May, when the tall mutondo trees of North-Western Province, Zambia, burst into flower at the end of the rainy season. The mutondo, one of the commonest trees of the vast miombo woodlands of Central Africa, yields high-quality nectar that African bees turn into a fragrant, light amber honey. The producers harvest beehives hanging from branches throughout the forest. Comb honey is packed in buckets and sold to producer cooperatives and private companies for refining and export to Europe. Large tracts of land in the miombo are certified organic - assuring the consumer of a natural, clean product and guaranteeing the producer a good market.
Over the last decade, when economic conditions have worsened for most rural folks in this remote part of Zambia, honey is one of the positive developments. Sales bring income to poor households. A kilo of raw honey earns a household about 40 US cents - almost half the average daily income. Demand is growing. New production technologies, such as the top bar hive, are encouraging thousands of women to become producers in their own right. Discerning buyers are gradually promoting more sustainable harvesting practices, e.g. by not buying the watery honey taken from the wild.

But much remains to be done to extend the benefits to more rural households. Producers and extension workers need to know how to increase yields and quality. Buyers need lower financial borrowing rates. The marketing and processing infrastructure requires urgent 
attention, particularly access to advanced technologies for honey testing and processing to meet the high standard requirements of western buyers. "It will be tough" says Evelyn Zimba, a socially responsible private sector buyer, "but if we keep at it we will succeed. Producers, processors, traders, exporters, government ... All of us pulling together. One day, Zambia will be on the world map as the best honey producing nation ever."

Zambia Alliance for People and Environment (ZAPE), with financial support from IFAD and
Sida, is assisting the Zambian Forestry Department to develop a bee-keeping policy that is sensitive to and supportive of all actors along the honey-supply chain, helping Zambia meet its export quotas of certified honey on the world market, earning much needed foreign exchange, and adding real growth to the national gross domestic product from sustainable use of miombo. (Guni Kokwe, ZAPE)

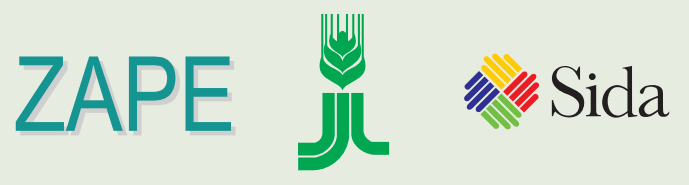

\section{Baobab surpassing cotton as the primary income source}

Chapeto lives in the remote district of Rushinga, in north-eastern Zimbabwe; a hot, dry, dusty place, where daily survival is a struggle. Chapeto runs a company called Creative Oils that produces oil from the seeds of the baobab tree. Three years ago he invested in an oil press, and now runs a small oil processing facility in Chimhanda village.

Creative Oils currently purchases six tonnes of seed per month from sixty rural producers in Rushinga. The producers are happy because they can earn as much as US\$ 180 in a season, almost doubling their income from cotton, the staple cash crop. Chapeto, too, is happy. He used to run a small tuck shop with an annual turnover of about US\$ 4,000 a year. Now his company produces over 360 litres of oil a month, from which he nets nearly US\$ 9,000 in a season.

Chapeto's success is due largely to his involvement with PhytoTrade Africa, the Southern African Natural Products Trade Association. In 2003, PhytoTrade Africa signed a joint venture agreement with Aldivia S.A., a French company specialising in the production of derivatives from natural plant oils for sale as cosmetic ingredients. Aldivia purchase baobab oil from Chapeto, which they then process and sell to the multinational company Bergasol, for incorporation into a new sunscreen. Chapeto could not have done this by himself but, through PhytoTrade Africa, his oil now reaches consumers across Europe and helps to battle skin cancer.

There are many products like baobab oil, derived from indigenous plant species in rural

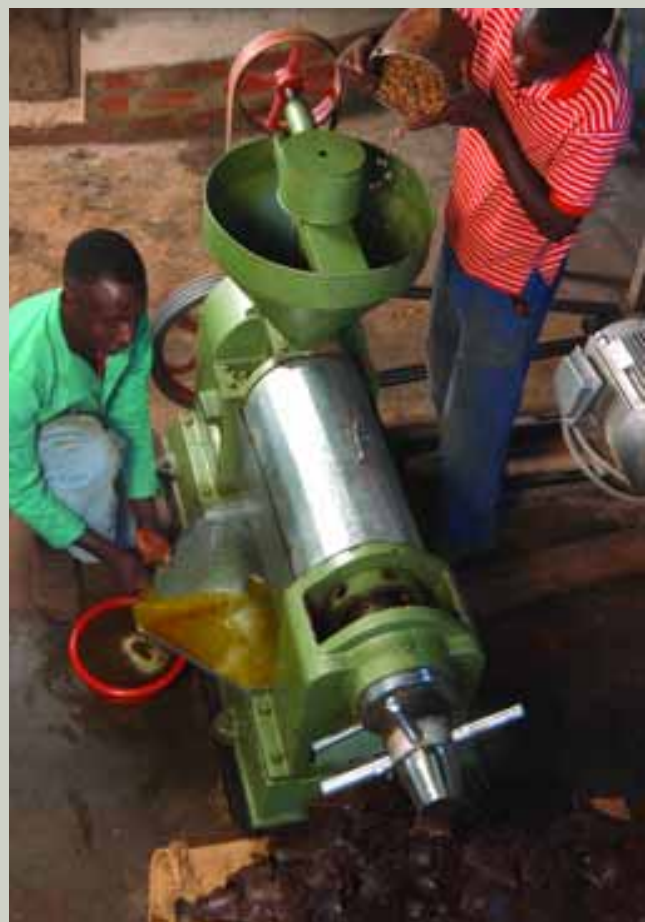

Producing oil from baobab

Photo by Gus le Breton

Africa and having significant commercial potential. For small-scale producers such as Chapeto, however, the barriers to developing markets for these products are formidable. But, by pooling resources with producers from across Southern Africa and helping create a powerful trade association to represent his interests, Chapeto has successfully overcome these barriers. (Gus le Breton, PhytoTrade)
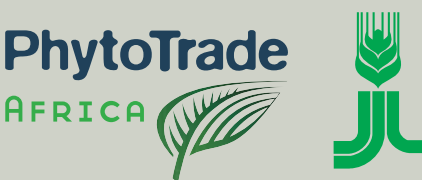


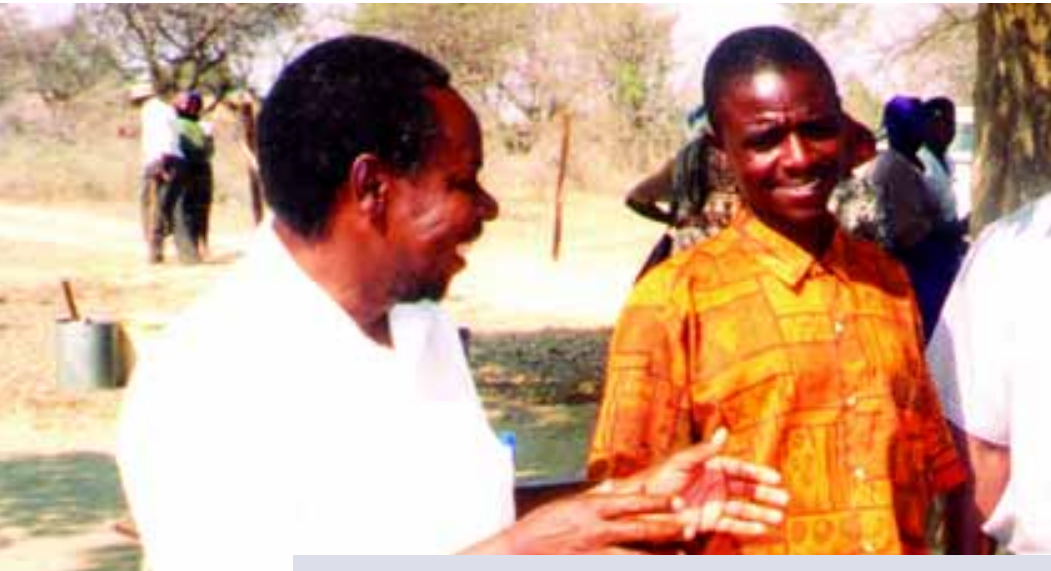

Using local markets in South Africa to secure livelihoods in the face of HIV/AIDS and increasing unemployment

Developing large external markets for forest products is one solution to enhancing peoples' livelihoods (as in the Zambian and Zimbabwe cases presented above). The other option is to expand local markets. For example, in Bushbuckridge, South Africa, a range of locallytraded forest products are securing livelihoods for increasing numbers of people. Consider the traditional hand-crafted brooms, made from wild grass and shrub species, and widely used by households: in Bushbuckridge alone, an area of only $1800 \mathrm{~km}^{2}$, about 390000 brooms are sold per year.

"Since I started doing this, my children no longer go to bed crying of hunger " replied a widowed mother of three when asked about the benefits of selling traditional brooms. For such women, trading means the difference between destitution or relying on relatives and neighbours for support, and independence and the ability to buy food and pay school fees. Analysing the profile of producers and their households shows that they are amongst the poorest and most marginalised people in Bushbuckridge. Lots of households are headed by women, many of whom are elderly and widowed. Most are illiterate or poorly educated. They have little or no other sources of cash income (usually only a child-welfare grant or pension); total household income is well below the poverty line for all households.

Many producers indicated that they had started making and selling brooms after being left to care for grandchildren following the death of the children's mothers, often from HIV/AIDS. Even where they had other sources of cash (such as pensions), this was insufficient to support these new dependents. Other producers entered the trade after the death of a breadwinner, or after retrenchment, when their husbands could not support them, or when they were unable to find jobs. Yet others sought to supplement existing meagre incomes. They all turned to something that they have the skills to do and for which a ready market exists. "Brooms are a way to earn money that we can learn to do ourselves" said one producer. Over a third of broom makers have been in the trade for only 1-5 years, reflecting the growing trend nationally towards increased involvement in trading natural resources as a response to rising unemployment, HIV/AIDS impacts and other economic hardships.

The incomes earned are generally modest, although some entrepreneurs, who market more widely, can earn incomes well above local wage rates. For example, several women who had worked as domestic workers for local households, where wages are particularly low, said that they could earn more from selling brooms. They could also be more independent and flexible. Net returns from broom sales ranged from US\$7 to US\$1680 per annum per household, with an average of over US\$ 300 . Even the small amounts can make a difference, allowing the purchase of food or some household item at a critical time. One producer improved her home, including tiling the roof, from the income earned from selling brooms.

Small changes to local markets for forest products, such as more secure resource-access rights, better organization amongst producers in harvesting and marketing, improved transportation, and less red tape for marketing, will benefit producers. Access to micro-credit would help people pay for transport to obtain more raw materials. (Sheona Shackleton, RHODES UNIVERSITY Rhodes University) 


\section{From garbage dumps to sustainable agroforests in Ouagadougou, Burkina Faso}

On the outskirts of Ouagadougou, Mrs Kaboré and her friends in AMIFOB (Association of Women Foresters of Burkina) initiated the Nabonswende local women's group. The group's name - "we ask God" - reflected the dire circumstances of these women. "We used to make a living from collecting and selling sand and gravel collected from an area used as a garbage dump - it was hard work in an unpleasant locality, and gave us very little money". Most of the group of 42 women are widows and must provide for their families.

With the help of $A M I F O B$ and funds from FEM/ONG (Fonds pour l'Environnement Mondial aux ONG), the group established a multi-purpose garden in the populous and poor outskirts of the capital city. The success of this initiative has earned it two first prizes, one national and one regional, from the the Permanent Interstate Committee for Drought Control in the Sahel (CILSS).

They have established an irrigated garden for vegetable production, a tree nursery with an annual production of 30,000 plants for sale or for planting on location, and a 3-ha arboretum with 600 trees of 75 local and exotic species, including medicinal plants, fruit trees, fodder trees and ornamentals. These agricultural and forestry activities have kick-started a range of

other activities. UNESCO built a shed that is used for training classes on topics as diverse as maternity, literacy and fish smoking. The arboretum is increasingly used to teach city schoolchildren which wild plants are important as food, medication etc. "We realised that many city kids had no idea what the different wild fruits and leaves that are important in the villages look like, even less the trees and shrubs they grow on. Many children cannot recognise the shea butter tree and have no idea that the soap they use daily is a tree product."

Such projects help to reduce poverty. Through selling tree seedlings and vegetables, the group generates over US\$ 3500 per annum, a substantial amount compared to their previous income. The women are better able to purchase basic clothing for their families, send their children to school, look after their health, eat better food, and they've become more conscious their local environment. The challenge to development practitioners now is to scale up such initiatives, to establish other such groups cost effectively? (AMIFOB)

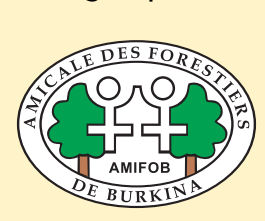

\section{The way forward}

To be successful, strategies to alleviate poverty in Africa must take account of the pivotal role of forests in sustaining rural livelihoods, especially those of the poor and marginalized. Poverty Reduction Strategy Papers (PRSPs) are key instruments for governments in Least Developed Countries to define policy and budgetary priorities. National Forest Programs (NFPs) are similarly important for forests. In both cases, however, the contribution of natural forests to sustaining the poor is ignored or underestimated. Local interventions based on forest products, often successfully promoted by non-governmental agencies, have yet to be scaled up to impact more people over wider areas. Strategies for doing this include distilling key information, advocacy, empowerment and engaging in policy processes. Forests and forestry must be put back on national and global agendas.

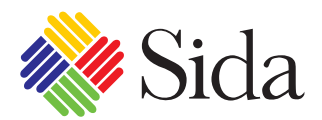

This Policy Brief was prepared by AMIFOB, Bruce Campbell (b.campbell@cgiar.org), Peter Frost, Guni Kokwe, Gus le Breton, Sheona Shackleton and Daniel Tiveau. The views expressed in this publication are those of the authors and not necessarily those of CIFOR. Sida has generously supported CIFOR's work on "Stimulating policy dialogue on sustainable management of Africa's dry forests" 